http://journal.uin-alauddin.ac.id/index.php/lamaisyir

Publisher: Fakultas Ekonomi dan Bisnis Islam UIN Alauddin Makassar

\title{
FATWA DSN MUI KLAUSAL DENDA DAN GANTI RUGI PADA SKIM KPR SYARIAH
}

\author{
Hasanuddin', Fakhruddin Mansyur ${ }^{2}$, dan Mega Mustika ${ }^{3}$ \\ Universitas Muhammadiyah Makassar \\ Jln. Sultan Alauddin No. 259. Makassar \\ hasanuddin@unismuh.ac.id ${ }^{1}$, fakhruddinmansyur@unismuh.ac.id ${ }^{2}$, \\ megamustika@unismuh.ac.id ${ }^{3}$
}

Received: 20 November 2020; Revised: 5 Desember 2020; Published: 31 Desember 2020

\begin{abstract}
ABSTRAK
Penelitian ini bertujuan untuk mengkaji fatwa DSN MUI 17/DSN-MUI/IX/2000 Tentang Sanksi atas Nasabah Mampu yang Menunda-nunda Pembayaran dan DSN MUI No. 43/DSN-MUI/VIII/2004 tentang Ganti Rugi (Ta'widh). Penelitian ini termasuk jenis penelitian kepustakaan, sumber data, buku, artikel, dokumen, dan laporan kegiatan bank. Hasil analisis penelitian bahwa penerapan sanksi denda dan ganti rugi nasabah oleh perbankan berdasarkan fatwa DSN MUI, beberapa ulama yang tidak sepakat hal itu dikarenakan fatwa tersebut tidak dicamtumkan kriteria secara spesifik, bahwa dalam perjalanan ada yang terkendala pembayaran seperti pedagang yang penghasilanya tidak menentu. Kajian ini ditemukan juga bahwa hal ini di berlakukan oleh perbankan syariah dikarenakan untuk mendisiplinkan nasabah dan adanya kerugian perusahaan.

Kata Kunci: Klausal Denda; Ganti Rugi; KPR Syariah.
\end{abstract}

\begin{abstract}
This research was conducted to examine the DSN MUI fatwa related to sanctions on fines and compensation for customers due to delaying payments, the sanctions given to capable customers who delay payments and to find out the application of the DSN-MUI Fatwa. This research was a qualitative research with primary data sources from interviews with the marketing coordinator and the service coordinator and documentation. The analysis in this discussion was descriptive qualitative data analysis. The results of this study indicate that the application of sanctions for fines and compensation for customers by banks based on the MUI DSN fatwa there were still some scholars who do not agree with this because the fatwa does not include specific criteria, thus the analysis of all Islamic banks taking mortgages in Islamic banking are capable people, but on the way there are those who are constrained by payment, such as traders whose income is uncertain. In this study it was also found that this was enforced by Islamic banking due to disciplining customers and company losses.
\end{abstract}

Key Words: Fine clause; compensation; sharia KPR. 


\section{PENDAHULUAN}

Aktivitas keuangan dan perbankan dipandang sebagi wahana bagi masyarakat untuk membawa mereka kepada kebaikan, paling tidak, pelaksanaan dua ajaran al-Qur' an yaitu prinsip saling ta'awun (membantu dan saling bekerja sama antara anggota masyarakat untuk kebaikan) dan prinsip menghindari iktinaz yaitu menahan dan membiarkan dana menganggur dan tidak diputar untuk transaksi yang bermanfaat, sedangkan dalam Islam dilarang untuk menahan barang yang dapat menghambat perekonomian sesuai dengan aturan dalam hukum islam.

Fatwa dan lembaga fatwa merupakan suatu institusi yang dibutuhkan masyarakat (Maimun, 2013). Klasifikasi hukum amaliyah atau fiqih mencakup dua wilayah utama dalam kehidupan mukallaf, yakni ibadah dan muamalah. Bidang ibadah erat kaitannya dengan aturan dalam rangka pemenuhan hak Allah swt, seperti ibadah mahdzah, nadzar, sumpah dan lain sebagainya. Sedangkan bidang mu'âmalah erat kaitannya dengan perilaku mukallaf dalam hubungan dengan sesamanya (Wahbah, 2008)

Lahirnya Undang-undang No. 10 Tahun 1998 sebagai amandemen terhadap Undang undang No. 7 Tahun 1992 tentang dunia perbankan telah membuka jalan bagi pengembangan bank syariah di Indonesia. Sebagai dampaknya lahir sejumlah bank berlabel syariah, baik dalam bentuk bank umum syariah ataupun unit usaha syariah dari bank konvensional. Hingga kini, ada 12 bank berlabel syariah, 8 unit usaha syariah dari bank konvensional, dan 83 bank pembiayaan rakyat syariah (BPRS), dibandingkan tahun 1992 yang hanya berjumlah satu bank syariah dan 79 bank pembiayaan rakyat syariah.

Lembaga Keuangan Syariah (LKS), baik perbankan ataupun non bank dalam menjalankan kegiatan operasionalnya harus sejalan dan sesuai dengan prinsip-prinsip syariah. Menurut Undang-undang Republik Indonesia No. 21 Tahun 2008 Tentang Perbankan Syariah, menyebutkan bahwa prinsip syariah adalah prinsip hukum Islam dalam kegiatan perbankan berdasarkan fatwa yang dikeluarkan oleh lembaga yang memiliki kewenangan dalam penetapan fatwa di bidang syariah. Penerapan prinsip-prinsip syariah juga harus mengacu pada etika bisnis secara islami yaitu berlandaskan pada al-Qur'an dan As-sunnah. Tidak hanya itu, etika bisnis dalam Islam juga mengacu pada tauhid, keseimbangan, kehendak bebas, pertanggungjawaban dan ikhsan. Masalah lain yang dihadapi oleh lembaga pemegang otoritas fatwa semacam DSN-MUI adalah masalah standarisasi dan regulasi yang ada (Aidil Novia, 2016). 
Lembaga keuangan syariah terdiri dari lembaga keuangan syariah bank dan non-bank. Lembaga keuangan bank syari'ah adalah lembaga bank yang merupakan sebuah lembaga intermediasi keuangan umumnya didirikan dengan kewenangan untuk menerima simpananuang, meminjamkan uang, dan menerbitkan promes atau yang dikenal sebagai banknote. Sedangkan menurut undang-undang perbankan, bank adalah badan usaha yang menghimpun dana dari masyarakat dalam bentuk simpanan dan menyalurkannya kepada masyarakat dalam bentuk kredit dan atau bentuk bentuk lainnya dalam rangka meningkatkan taraf hidup rakyat banyak.

Fatwa MUI menjadi sangat penting dalam Lembaga keuangan Syariah, hal ini sebagai pedoman disebabkan akad atau perjanjian yang digunakan harus berdasar dari fatwa itu sendiri, Pada fatwa MUI ini tentang klausal denda bagi nasabah perbankan Syariah dibutuhkan kajian mendalam bagi kalangan yang memiliki penghasilan tidak tetap seperti pengusaha/pedagang yang pendapatanya menyesuaikan konsumen yang tertarik pada barangnya.

Penerapan denda murabahah pada perbankan syariah menjelaskan sanksi didasarkan pada prinsip ta'zir yaitu bertujuan agar nasabah lebih disiplin dalam melaksanakan kewajibannya. Sebab dengan menerapkan sejumlah uang lebih dalam pembayaran angsuran akan membuat nasabah lebih disiplin dalam melakukan pembayaran angsuran Artinya, seorang nasabah dikatakan terkena denda apabila nasabah tersebut melewati tanggal jatuh tempo yang telah ditetapkan oleh pihak bank dalam pembayaran angsuran. Sanksi denda murabahah pada salah satu perbankan syariah tidak berdasarkan pada lama nya waktu keterlambatan seorang nasabah dalam pembayaran angsuran. Melainkan menggunakan sistem proses tiring atau range. Tiring. (Fadli, 2017)

Penelitian ini menganalisis dari sisi kebijakan dari perbankan terkait denda bagi nasabah pedagang yang menunda-nunda angsuran KPR nya. Hal ini yang menjadi dasar utama dalam penelitian ini, bahwa apa bedanya KPR Bank Konvensional menerapkan denda keterlambatan terhadap keterlambatan tempo pembayaran angsuran, sedangkan dalam KPR Bank Syaraih Denda keterlambatan (seharusnya) tidak boleh ada, namun realitasnya masih ada denda. Namun peneliti lebih fokus pada KPR bank syariah bagi pedangang, hal ini dikarenakan pedagang tidak memiliki penghasilan tetap jika di bandingkan karyawan pada perusahaan. Jika pedagang mengalami kesulitan dalam daganganya maka tetap di kenai denda atas keterlambatan pembayaran, inilah yang menjadi menarik untuk diteliti. 


\section{METODE PENELITIAN}

Penelitian ini menggunakan metode penelitian kepustakaan dengan memusatkan satu objek yang diangkat sebagai sebuah kasus dengan mengamati informan secara langsung yang berkaitan dengan sistem sanksi dangan ganti rugi bagi nasabag KPR Bank Syariah. Jenis data yang digunakan adalah sekunder diperoleh dari hasil penulusaran buku, artikel, dokumen dan laporan bank data terkait fatwa MUI Nomor. 17 tahun 2000 dan Nomor 43 Tahun 2004. Teknik pengumpulan data pada penelitian dari buku, literatur, catatan, serta berbagai laporan yang berkaitan dengan masalah yang ingin dipecahkan. Hasil analisis data berupa pemaparan mengenai situasi yang diteliti yang disajiakan dalam bentuk uraian naratif, tahap analisis data, tahap pertama reduksi data dengan merangkum data dari kajian. Tahap kedua penyajian data diperoleh dari kumpulan seluruh informasi dari buku, artikel, internet, dan laporan yang sudah tersusun. Tahap ketiga penarikan kesimpulan digunakan untuk jawaban setiap masalah yang diteliti.

\section{HASIL DAN PEMBAHASAN}

\section{Penerapan Klausal Denda dan Ganti Rugi pada skim KPR}

Secara umum, dalam hukum muamalah Syari'ah terdapat asas-asas umum yang melandasi penegakan dan pelaksanaan akad, diantaranya adalah asas kebebasan berakad (mabda hurriyyah al-ta'aqud). Suatu prinsip hukum yang menyatakan bahwa setiap orang dapat membuat akad jenis apapun tanpa terikat kepada nama-nama yang telah ditentukan dalam teks Syari'ah (nash alQur'an dan Hadis), begitu juga kebebasan memasukan klausul apa saja ke dalam akad yang dibuatnya sesuai dengan kepentingannya sejauh tidak berakibat pada terjadinya kontradiksi dengan ketentuan al-Qur'an dan Hadis. Asas kebebasan berakad ini diformulasikan dalam sebuah kaidah fiqh yang berbunyi (Zity, 2008).

"Hukum asal atas segala bentuk akad dan syarat/klausul yang menyertai akad adalah halal dan mubah kecuali ada dalil yang melarangnya"

Kaidah tersebut menegaskan bahwa setiap bentuk akad dan syarat itu sah dan boleh selama tidak ada dalil al-Qur'an, Hadis, Ijma' atau Qiyas yang melarang akad atau syarat tersebut. Beberapa ulama berbeda pendapat dalam masalah dalil yang dapat membatalkan atau mengharamkan suatu akad atau transaksi. Imam Ahmad membenarkan bahwa Ijma' dan Qiyas bisa menjadi 
Hasanuddin, at.al,: Fine clause; compensation; sharia KPR.

dasar penetapan syarat dan akad tetapi keduanya tidak bisa dijadikan dasar pembatalan akad tersebut. Hanya nash al-Qur'an dan Hadis yang menjadi dasar penetapan pembatalan suatu akad, namun mayoritas ulama pendapat bahwa Qiyas dan Ijma' dapat dijadikan hujah dalam membatalkan akad dan syarat, (Wahbah Al-Zuhaili, 2008)

Penundaan pembayaran hutang oleh debitur telah menjadi pembicaraan para ulama dalam khazanah fiqh Islam. Masalah ini telah muncul sejak dari zaman Nabi saw sendiri. Hal ini dibuktikan dari Hadis yang menegaskan bahwa "Penunda-nundaan pembayaran hutang oleh orang mampu adalah suatu kezaliman". Begitu juga Hadis yang menyatakan "Penunda-nundaan pembayaran hutang dari orang yang mampu merupakan kezaliman yang menghalalkan pencercaan nama baiknya dan pengenaan hukuman" (Wahbah Al-Zuhaili, 2008).

Tanggungjawab ganti rugi dalam hukum perdata terbagi menjadi dua, yakni tanggungjawab ganti rugi karena akad (al-mas'ûliyah al-ta'aqudiyah) dan tanggungjawab ganti rugi karena keteledoran (almas'îliyah al-taqshîriyah). Tanggungjawab ganti rugi karena akad (al-mas'ûliyah al-ta'aqudiyah) terkait dengan menyalahi keharusan akad seperti penjual tidak mau menyerahkan barang dagangannya atau penyewa tidak mau menyerahkan barang sewaannya. Sedangkan tanggungjawab ganti rugi karena keteledoran atau kecerobohan (al-mas'ûliyah al-taqshîriyah) terjadi karena salah satu pihak menyalahi aturan sehingga terjadi pengghashaban atau kerusakan benda karena kelalaian.

Sanksi yang dikenakan atas penundaan pembayaran didasarkan pada prinsip $t a^{\prime} z i r$, agar nasabah lebih disiplin dalam melaksanakan kewajibannya. Dengan demkian, nasabah yang tidak atau belum mampu membayar karena kondisi force majeur tidak boleh dikenakan sanksi. Bagi bank syariah, dana denda yang diterima harus diperuntukkan sebagai dana social, (Fadli, 2017).

Merujuk fatwa Majelis Ulama Indonesia (MUI) Nomor 43 tahun 2004 tentang Ganti Rugi (dhamân/ta'wî̉dh) pembahasannya dibatasi, dimana ganti rugi hanya dapat diterapkan pada transaksi (akad) yang menimbulkan hutang piutang (dain), seperti Salam, Istishnâ', Murâbahah dan Ijârah. Sedangkan dalam akad Mudhârabah dan Musyârakah, ganti rugi hanya boleh dikenakan oleh Shâhibul Mâl atau salah satu pihak dalam musyarakah apabila bagian keuntungannya sudah jelas tetapi tidak dibayarkan. Berdasarkan latar belakang tersebut, maka menurut hemat penulis perlu menjelaskan bahwa implementasi ganti rugi dalam akad muamalah bukan hanya pada akad Salam, Istishnâ', 
Murâbahah dan Ijârah. Tetapi lebih luas implementasinya dalam berbagai akad muamalah (perdata) bahkan jinayah (pidana).

Produk pembiayaan KPR yang digunakan dalam perbankan syariah memiliki berbagai macam perbedaan dengan KPR (Kredit Kepemilikan Rumah) di perbankan konvensional. Hal ini merupakan implikasi dari perbedaan prinsipal yang diterapkan perbankan syariah dan perbankan konvensional, yaitu konsep bagi hasil dan kerugian (profit and loss sharing) sebagai pengganti sistem bunga perbankan konvensional. Produk pembiayaan kepemilikan rumah ini, terdapat beberapa perbedaan antara perbankan syariah dan perbankan konvensional, di antaranya adalah; pemberlakuan sistem kredit dan sistem mark up, kebolehan dan ketidakbolehan tawar menawar (bergaining position) antara nasabah dengan bank,

Kewajiban $t a^{\prime}$ widh dapat berbeda baik pada karakter maupun tujuannya. Ta'wid dapat ditetapkan untuk melindungi hak-hak individu. Karena kewajiban pada $t a^{\prime} w i d$ bertujuan untuk mengganti atau menutupi kerugian. Menurut ketentuan pasal 36 dalam buku Kompilasi Hukum Ekonomi Syariah, pelaksanaan sanksi dapat dilakukan terhadap nasabah yang melakukan ingkar janji apabila melakukan kesalahannya sebagai berikut: a) Tidak melakukan apa yang dijanjikan untuk melakukannya, b) Melaksanakan apa yang dijanjikannya tetapi tidak sebagaimana dijanjikannya, c) Melakukan apa yang dijanjikannya, tetapi terlambat, d) Melakukan sesuatu yang menurut perjanjian tidak boleh dilakukan, (Mahkamah Agung RI, 2013)

Sedangkan menurut ketentuan pasal 39 kompilasi Hukum Ekonomi Syariah, pembayaran ganti rugi dapat dijatuhkan apabila: a) Pihak yang melakukan ingkar janji setelah ingkar janji, tetap melakukan ingkar janji, b) Sesuatu yang harus diberikan atau dibutuhkannya, hanya dapat diberikan atau dibuat dalam tenggang waktu yang telah ditentukannya, c) Pihak yang melakukan ingkar janji tidak dapat membuktikan bahwa perbuatan ingkar janji yang dilakukannya tidak di bawah paksaan.

Sebagaimana telah dijelaskan tentang sanksi atas nasabah mampu yang menunda-nunda pembayaran. Hal ini dilakukan analisis oleh peneliti bahwa Yang menjadi pedoman dalam mengenakan denda kepada nasabah harus memenuhi kriteria yaitu sebagi berikut: a) harta yang dimiliki nasabah: harta benda yang dimiliki oleh nasabah ketika diadakan penagihan bias dikatakan dalam barang-barang tersier dan kepemilikannya memang milik nasabah itu sendiri bukan dari pemberian orang lain. Maka harta ini memang benar miliki nasabah, maka nasabah dapat dikategorikan dalam nasabah mampu, b) penghasilan nasabah: pekerjaan yang dimiliki nasabah saat mengajukan 
pembiayan dapat dijadikan tolok ukur berapa jumlah penghasilan nasabah tersebut. Sehingga dapat dikatakan nasabah itu bisa dikenakan denda atau tidak, c) usaha nasabah: keadaan usaha yang digeluti oleh nasabah tersebut dapat dijadikan tolok ukur bahwa nasabah itu mampu atau tidak. Sebab apabila usaha yang digeluti nasabah tersebut berjalan lancar dan berkembang pesat maka nasabah tersebut bisa dikatakan nasabah mampu dan dikenakan denda, d) keterangan tetangga sekitar rumah nasabah: informasi dari tetangga sekitar rumah nasabah dapat dijadikan untuk menanyakan kebenaran dari keterangan nasabah tentang keadaan ekonomi yang dialami sampai permasalahan yang sedang dihadapi nasabah. Sebab tetangga sekiatar rumah nasabah merupakan orang yang paham betul keadaan keseharian nasabah dan bisa memantau secara kasap mata tentang keadaan yang sebenarnya dari nasabah.

MUI menetapkan bahwa nasabah yang memiliki kemampuan untuk membayar namun dengan sengaja menunda pembayaran serta tidak memiliki keinginan dan niat baik untuk membayar kewajiban atau hutangnya, maka boleh dikenai sanksi. Sanksi dapat berbentuk denda berupa sejumlah uang yang nominalnya ditetapkan atas dasar kesepakatan dan dibuat saat akad ditandatangani. Kompensasi yang demikian ini diperbolehkan jika keterlambatannya tidak dikarenakan peristiwa tertentu yang tidak dapat dielakkan force majeure (zawawi, 2016), tidak boleh dikenakan sanksi. Dasar atas sanksi ini yaitu prinsip ta'zir yaitu prinsip bahwa tujuan dari denda tersebut adalah agar nasabah lebih disiplin dalam melaksanakan kewajibannya. Dana yang berasal dari denda tersebut selanjutnya diperuntukkan sebagai dana sosial bank syariah.

\section{Ketentuan Denda dan Ganti Rugi Pada Akad}

Pada awal tahun 1999, Dewan Syariah Nasional secara resmi didirikan sebagai lembaga syariah yang bertugas mengayomi dan mengawasi operasional aktifitas perekonomian Lembaga Keuangan Syariah (LKS). Selain itu juga untuk menampung berbagai masalah/kasus yang memerlukan fatwa agar diperoleh kesamaan dalam penanganannya oleh masing-masing dewan pengawas syariah (DPS) yang ada di masing-masing LKS.

Dari ketentuan-ketentuan yang telah diatur, jika nasabah dalam hal ini tidak dapat mengembalikan atau terjadinya wanprestasi. LKS dapat memberikan sanksi kepada nasabah jika: 1) Ketika nasabah tidak menunjukkan keinginan mengembalikan sebagian atau seluruh 
Beberapa fatwa telah dikeluarkan oleh lembaga tersebut guna mendukung kinerja lembaga keuangan syariah di Indonesia salah satunya perbankan syariah. Ketentuan terhadap akad kewajibannya dan bukan karena ketidak mampuannya, LKS dapat menjatuhkan sanksi kepada nasabah; 2) Sanksi yang dijatuhkan kepada nasabah sebagaimana dimaksud butir 1 dapat berupa dan tidak terbatas pada penjualan barang jaminan. Jika barang jaminan tidak mencukupi, nasabah tetap harus memenuhi kewajibannya secara penuh, (Farid, 2013).murabahah secara umum diatur dalam fatwa No:04/DSNMUI/IV/2000 tentang Murabahah. Ketentuan denda ta'zir diatur dalam fatwa no.17/DSN-MUI/IX/2000 tentang sanksi atas nasabah mampu yang menundanunda pembayaran. Beberapa ketentuan umum yang disebutkan mengenai denda $t a^{\prime} z i r$ yakni : 1) Sanksi yang disebut dalam fatwa ini adalah sanksi yang dikenakan LKS kepada nasabah yang mampu membayar, tetapi menundanunda pembayaran dengan disengaja, 2) Nasabah yang tidak/belum mampu membayar disebabkan force majeur tidak boleh dikenakan sanksi, 3) Nasabah mampu yang menunda-nunda pembayaran dan/atau tidak mempunyai kemauan dan itikad baik untuk membayar hutangnya boleh dikenakan sanksi, 4) Sanksi didasarkan pada prinsip ta'zir, yaitu bertujuan agar nasabah lebih disiplin dalam melaksanakan kewajibannya, 5) Sanksi dapat berupa denda sejumlah uang yang besarnya ditentukan atas dasar kesepakatan dan dibuat saat akad ditandatangani, 6) Dana yang berasal dari denda diperuntukkan sebagai dana sosial.

Hal ini mengigat bahwa secara tradisional, setiap bentuk penambahan apa pun terhadap pembiayaan merupakan bentuk-bentyk riba. Namun, PBI No. 7/46/PBI/2005 tentang akad perhimpunan dana bagi bank yang melaksanakan kegiatan usaha berdasarkan prinsip syariah, yaitu berkenaan dengan pengaturan ganti kerugian ( $\left.t a^{\prime} w i d h\right)$ dalam pembiayaan dimaksud memberi kemungkinan pengenaan ganti kerugian dalam hal dan dengan ketentuan-ketentuan yang telah diatur. Adrian sutendi(Sutedi, 2009)

Sedangkan ta"widh diatur pada fatwa no.43/DSN-MUI/VIII/2004 tentang Ganti Rugi ( $T a$ "widh) yang berbunyi (Fauzan, 2007): Ketentuan Umum, 1) Ganti rugi ( $t a$ 'widh) hanya boleh dikenakan atas pihak yang dengan sengaja atau karena kelalaian melakukan sesuatu yang menyimpang dari ketentuan akad dan menimbulkan kerugian pada pihak lain, 2) Kerugian yang dapat dikenakan $t a$ "widh sebagaimana dimaksud dalam ayat 1 adalah kerugian riil yang dapat diperhitungkan dengan jelas, 3) Kerugian riil sebagaimana dimaksud ayat 2 adalah biaya-biaya riil yg dikeluarkan dalam rangka penagihan hak yg seharusnya dibayarkan, 4) Besar ganti rugi (ta widh) adalah 
sesuai dengan nilai kerugian riil (real loss) yang pasti dialami (fixed cost) dalam transaksi tersebut dan bukan kerugian yang diperkirakan akan terjadi (potential loss) karena adanya peluang yang hilang (opportunity loss atau al-furshah al-dhai"ah), 5) Ganti rugi (ta 'widh) hanya boleh dikenakan pada transaksi (akad) yang menimbulkan utang piutang (dain), seperti salam, istishna" serta murabahah dan ijarah, 6) Dalam akad Mudharabah dan Musyarakah, ganti rugi hanya boleh dikenakan oleh shahibul mal atau salah satu pihak dalam musyarakah apabila bagian keuntungannya sudah jelas tetapi tidak dibayarkan, (Dewan Syariah Nasional MUI, 2014) .

Ketentuan Khusus: 1) Ganti rugi yang diterima dalam transaksi di LKS dapat diakui sebagai hak (pendapatan) bagi pihak yang menerimanya, 2) Jumlah ganti rugi besarnya harus tetap sesuai dengan kerugian riil dan tata cara pembayarannya tergantung kesepakatan para pihak, 3) Besarnya ganti rugi ini tidak boleh dicantumkan dalam akad, 4) Pihak yang cedera janji bertanggung jawab atas biaya perkara dan biaya lainnya yang timbul akibat proses penyelesaian perkara.

Ketentuan terkait sanksi denda pada murabahah juga dapat kita temukan di Buku Standar Produk Murabahah yang dikeluarkan oleh Otoritas Jasa Keuangan (OJK). Berikut beberapa ketentuan yang termaktub dalam poin 3.19 tentang Standar Wanprestasi dan 3.20 tentang Standar Denda ( $\left.T a^{\prime} z i r\right)$ dan Ganti Rugi (Ta'widh).

Standar Wanprestasi dalam Buku Standar Produk Murabahah oleh OJK: 1) Wanprestasi adalah kegagalan Nasabah dalam memenuhi kewajiban atau segala hal yang ditentukan dan bersama dalam kontrak sehingga menimbulkan kerugian bagi Bank baik dalam berupa penyusutan nilai modal maupun pengurang dan nilai bagi hasil untuk Bank, 2) Jika wanprestasi terjadi akibat kelalaian nasabah yang mengakibatkan kerugian pihak Bank, maka Bank berhak mendapatkan ganti rugi ( $\left.t a^{\prime} w i d h\right)$

Standar Denda ( $\left.T a^{\prime} z i r\right)$ dan Ganti Rugi (Ta'widh): 1) Bank dapat memberikan sanksi kepada Nasabah yang terbukti mampu bayar namun melakukan tunggakan atas pembayaran angsuran dan/atau wanprestasi atas setiap ketentuan yang telah disepakati dalam kontrak, 2) Sanksi yang dapat diterapkan adalah berupa denda ( $\left.t a^{\prime} z i r\right)$ dan/atau ganti rugi ( $t a^{\prime} w i d h$ ). Bank dapat menerapkan salah satu atau keduanya sesuai dengan syarat dan kondisi yang dijelaskan dalam standar ini, 3) Denda atas tunggakan ( $t a^{\prime} z i r$ ) harus diperuntukkan sebagai dana social atau dana kebajikan sementara ganti rugi 
(ta'widh) dapat diakui sebagai pendapatan dalam pembukuan Bank, 4) Denda atas tunggakan (ta "zir) hanya dikenakan kepada Nasabah jika Nasabah terbukti lalai atas kewajiban pembayaran angsurannya, 5) Kelalaian Nasabah didefinisikan sebagai kesalahan yang dilakukan oleh Nasabah dalam hal keterlambatan pembayaran atas pembiayaan yang diberikan dalam kontrak ini.

Ketentuan mengenai pembebanan ganti rugi ( $t a$ "widh) kepada Nasabah dibatasi oleh beberapa standar berikut ini: a) Ganti rugi dikenakan kepada nasabah yang memang sengaja atau karena lalai melakukan sesuatu yang menyimpang dari akad dan mengakibatkan kerugian pada Bank, b) Besarnya ganti rugi yang dapat diakui sebagai pendapatan bank adalah sesuai dengan kerugian riil (real loss) dan bukan kerugian yang diperkirakan akan terjadi (potential loss), c) Bank hanya dapat mengenakan ganti rugi pada keuntungan Bank yang sudah jelas tidak dibayarkan oleh nasabah, d) Klausul ganti rugi harus ditetapkan secara jelas dalam akad dan dipahami oleh nasabah, d) Penetapan ganti rugi atas kerugian riil ditetapkan berdasarkan kesepakatan antara Bank dan Nasabah.

Ketentuan-ketentuan mengenai sanksi yang dapat diberikan pada nasabah wanprestasi yang tersebut dalam Buku Standar Produk Murabahah yang dikeluarkan OJK bersesuain dengan ketentuan yang telah ditetapkan oleh Fatwa DSN-MUI. "Buku Standar Produk Murabahah ini sebagai salah satu upaya standarisasi produk perbankan syariah secara serial yang dilakukan oleh OJK bekerjasama dengan pelaku industri dan Dewan Syariah Nasional serta nara sumber lainnya." sebut Pak Mulya E. Siregar sebagai sambutan dalam buku standar tersebut.

Sebagaimana yang telah ditetapkan, ta"zir dan ta"widh memiliki perbedaan masing-masing diantaranya mencakup kondisinya, perhitungannya, dan pengakuannya dalam laporan keuangan. Beberapa perbedaan yang dapat dirangkum antara lain : 
Hasanuddin, at.al,: Fine clause; compensation; sharia KPR.

Tabel 1. Perbedaan $T a^{\prime} z i r$ dan $T a^{\prime}$ widh

\begin{tabular}{|c|c|c|}
\hline $\begin{array}{c}\text { Aspek } \\
\text { perbedaan }\end{array}$ & $T a^{\prime} z i r$ & $T a^{\prime} w i d h$ \\
\hline Kondisi & $\begin{array}{l}\text { Tidak mensyaratkan } \\
\text { adanya } \\
\text { kerugian yang dialami } \\
\text { bank }\end{array}$ & $\begin{array}{l}\text { Mensyaratkan adanya kerugian } \\
\text { riil yang diakibatkan oleh biaya } \\
\text { penagihan yang keluar }\end{array}$ \\
\hline Perhitungan & $\begin{array}{l}\text { Dapat berupa uang yang } \\
\text { nilainya berdasarkan } \\
\text { kesepakatan kontrak di } \\
\text { awal }\end{array}$ & $\begin{array}{l}\text { Kerugian riil yang memang } \\
\text { benar dialami bank, bukan } \\
\text { kerugian yang diperkirakan } \\
\text { akan terjadi }\end{array}$ \\
\hline Pengakuan & $\begin{array}{l}\text { Sebagai dana sosial atau } \\
\text { dana } \\
\text { kebajikan }\end{array}$ & $\begin{array}{l}\text { Sebagai pendapatan dalam } \\
\text { pembukuan bank }\end{array}$ \\
\hline
\end{tabular}

\section{Kritikan atas Pemberlakuan Denda pada nasabah KPR bagi pedagang}

Penelitian ini dikaji secara teori dan dilaksanakan secara praktek, hal ini dirasakan oleh nasabah bahwa penetapan nasabah yang berhak mendapatkan denda masih secara umum dalam artian semua nasabah menandatangi kontrak di awal kesepakan itu artinya sudah di peringatkan bahwa ada denda, namun bagi pedagang pendapatanya tidak menentu, sehingga ini di mungkinkan untuk merugikan nasabah dikarenakan nasabah tidak semua dari karyawan ataupun pengusaha, ada dari pedagang dan lain-lain yang penghasilanya ditentukan oleh pelanggan. 
Tabel 2. Perbedaan Pendapat Mengenai Denda Ta"zir

\begin{tabular}{|c|c|c|}
\hline & Boleh & Tidak Boleh \\
\hline $\begin{array}{l}\text { Ulama } \\
\text { yang } \\
\text { berpenda } \\
\text { pat }\end{array}$ & $\begin{array}{l}\text { 1. Prof. Dr. Wahbah } \\
\text { Zuhayli, } \\
\text { 2. Dr. Muhammad } \\
\text { Syubair, AAOIFI, } \\
\text { 3. DSN MUI }\end{array}$ & $\begin{array}{l}\text { 1. Syaikh Abdullah bin Manie, } \\
\text { 2. Prof.Dr. Al Qarh Daghi, } \\
\text { 3. Dr. Fahmi Abu Sunnah, } \\
\text { 4. Dr. Iyadh al Anzi, } \\
\text { 5. Dewan Fikih Islam Liga Muslim } \\
\text { Dunia }\end{array}$ \\
\hline Argumen & $\begin{array}{l}\text { 1. Bolehnya menerapkan } \\
\text { sanksi dengan } \\
\text { mengambil harta } \\
\text { 2. Bolehnya mengenakan } \\
\text { hukuman bagi orang } \\
\text { yang } \\
\text { menunda pembayaran } \\
\text { utang } \\
\text { 3. Denda yang dibayar } \\
\text { bukanlah riba karena } \\
\text { diperuntukkan untuk } \\
\text { kebutuhan social } \\
\text { 4. Perjanjian dibuat agar } \\
\text { debitur memenuhi } \\
\text { kewajibannya, dan } \\
\text { perjanjian haruslah } \\
\text { dipenuhi }\end{array}$ & $\begin{array}{l}\text { 1. Tidak boleh menerapkan sanksi } \\
\text { dengan mengambil harta } \\
\text { 2. Hukuman yang dibolehkan } \\
\text { dikenakan kepada orang yang } \\
\text { menunda pembayaran denda } \\
\text { adalah dengan pencemaran } \\
\text { nama baik atau penjara. } \\
\text { 3. Kreditur (bank) yang menerima } \\
\text { dana denda, mendapatkan } \\
\text { keuntungan berupa promosi dan } \\
\text { ini termasuk riba } \\
\text { 4. Perjanjian yang dibuat untuk } \\
\text { menghalalkan suatu yang haram } \\
\text { tidak boleh dipenuhi }\end{array}$ \\
\hline $\begin{array}{l}\text { Penc } \\
\text { Penv }\end{array}$ & $\begin{array}{l}\text { 1. jika di bolehkan } \\
\text { bukanlah kerugian } \\
\text { perusahaan tapi untuk } \\
\text { mendisiplingkan } \\
\text { karyawan } \\
\text { 2. perlu ada } \\
\text { pengklasifikasian } \\
\text { untuk menetapkan } \\
\text { ganti rugi }\end{array}$ & $\begin{array}{l}\text { 1. tidak boleh dikarenakan } \\
\text { merugikan perusahaan padahal } \\
\text { dana ganti kerugian tersebut } \\
\text { digunakan untuk social } \\
\text { 2. masih mencari payung hukum } \\
\text { untuk tetap memungut hal } \\
\text { haram untuk keuntungan } \\
\text { sepihak }\end{array}$ \\
\hline
\end{tabular}

Beberapa lembaga fatwa yang mengharamkan $t a^{\prime}$ widh, seperti yang disampaikan Dewan Fikih Islam Liga Muslim Dunia (Muslim World League) (AAOIFI, 2010): 
Hasanuddin, at.al,: Fine clause; compensation; sharia KPR.

"Apabila Kreditur memberikan suatu kondisi bagi debitur, dimana debitur akan membayar kepada kreditur sejumlah uang baik sebagai hukuman denda yang tetap atau dengan sebuah rasio, pada saat debitur menunda pembayaran angsuran yang telah disepakati pada periode tertentu, maka kondisi tersebut tidak sah atau ketentuan tersebut tidak boleh dipenuhi, baik ketentuan tersebut berasal dari bank ataupun orang lain, karena hal tersebut merupakan riba Jahiliyyah (Periode ketidaktahuan sebelum Islam) yang telah Alquran larang."

AOIFI juga menyatakan dalam Standar Syariah Nomor 3 Penundaan Pembayaran oleh Debitur pada pasal 2/1(b) dan 2/1(c) :

"2/1(b) It is not permitted to stipulate any financial compensation, either in cash or in other consideration, as a penalty clause in respect of a delay by a debtor in settling his debt, whether or not the amount of such compensation is predetermined; this applies both to compensation in respect of loss of income (opportunity loss) and in respect of a loss due to a change in the value of the currency of the debt.

2/1(c) It is not permitted to make a judicial demand on a debtor in default to pay financial compensation, in the form either of cash or of other consideration, for delay in settling his debt."

Keputusan Majma" Al Fiqh Al Islami (divisi Fikih OKI) No.51 (2/6) 1990 yang berbunyi, "Bagi nasabah yang mampu haram hukumnya menundanunda

kewajiban pembayaran yang telah jatuh tempo. Meskipun demikian, Syariat tidak membolehkan penjual membuat persyaratan ta"widh (ganti rugi) pada saat nasabah terlambat melunasi kewajiban pembayaran. (Tarmizi, 2019).

Pada prinsipnya, produk syariah didukung dengan lahirnya UU No 21 tahun 2008, sehingga telah jelas adanya pengakuan dari hukum positif bahwa prinsip syariah dapat diterapkan secara menyeluruh, (Baidhowi, 2017)

Ibnu Abdil Barr berkata, "Ulama Salaf dan Khalaf sepakat bahwa riba yang diharamkan Alquran adalah menarik uang ganti rugi ( $t a$ "widh) dari debitur yang terlambat membayar kewajibannya setelah jatuh tempo. 
Tabel 3. Perbedaan Pendapat Mengenai Denda Ta"widh

\begin{tabular}{|c|c|c|}
\hline & Boleh & Tidak Boleh \\
\hline $\begin{array}{l}\text { Ulama yang } \\
\text { berpendapat }\end{array}$ & $\begin{array}{l}\text { 1. Syekh Mustafa Zarqa, } \\
\text { 2. Syaikh abdullah bin Mani } \\
\text { 3. Abd al-hamid } \\
\text { Mahmud al-Ba li, } \\
\text { 4. Isham Anas al Zaftawi, } \\
\text { 5. DSN-MUI. }\end{array}$ & $\begin{array}{l}\text { 1. Dr. Iyadh al Anzi, } \\
\text { 2. Dewan Fikih Islam Liga } \\
\text { Muslim Dunia, } \\
\text { 3. AAOIFI, } \\
\text { 4. Divisi Fikih OKI. }\end{array}$ \\
\hline Argumen & $\begin{array}{l}\text { 1. Bolehnya menerapkan } \\
\text { sanksi dengan mengambil } \\
\text { harta. } \\
\text { 2. Bolehnya mengenakan } \\
\text { hukuman bagi orang yang } \\
\text { menunda pembayaran utang } \\
\text { 3. Menghilangkan mudarat } \\
\text { berupa kerugian yang } \\
\text { dialami kreditur akibat } \\
\text { penundaan pembayaran } \\
\text { oleh debitur dengan } \\
\text { pembayaran ganti rugi } \\
\text { 4. Bukan termasuk riba, karena } \\
\text { kreditur tidak mendapatkan } \\
\text { manfaat. }\end{array}$ & $\begin{array}{l}\text { 1. Tidak boleh } \\
\text { menerapkan sanksi } \\
\text { dengan mengambil } \\
\text { harta. } \\
\text { 2. Hukuman yang } \\
\text { dibolehkan dikenakan } \\
\text { kepada orang yang } \\
\text { menunda pembayaran } \\
\text { denda adalah dengan } \\
\text { pencemaran nama baik } \\
\text { atau penjara. } \\
\text { Menghilangkan } \\
\text { kerugian bias dengan } \\
\text { cara lain, sseperti } \\
\text { eksekusi jaminan atau } \\
\text { seluruh angsuran } \\
\text { menjadi tunai. } \\
\text { Termasuk riba yang } \\
\text { diharamkan dalam al- } \\
\text { Qur'an. }\end{array}$ \\
\hline $\begin{array}{l}\text { Pendapat } \\
\text { Penulis }\end{array}$ & $\begin{array}{l}\text { 1. Jika denda diterapkan bagi } \\
\text { yang sengaja menunda } \\
\text { pembayaran maka di } \\
\text { perlukan kriterian yang } \\
\text { menunda karena dalam } \\
\text { berjalanya usaha kadang } \\
\text { mengalami kerugian }\end{array}$ & $\begin{array}{l}\text { 1. Denda bagi siapa saja } \\
\text { itu tidak boleh karena } \\
\text { bagi orang yang tidak } \\
\text { bertanggung jawab } \\
\text { dapat mempergunakan } \\
\text { yang tidak sesuai } \\
\text { dengan syariah }\end{array}$ \\
\hline
\end{tabular}


Hasanuddin, at.al,: Fine clause; compensation; sharia KPR.

2. Dana hasil denda di perjelas jika alas an dikenakan denda karena merugikan perusahaan lalu mengapa di jadikan sebagai dana sosial
2. Kesepakatan diawal untuk semua nasabah telah memandatangi kontrak bahwa keterlambatan pembayaran akan dikenakan sanksi tanpa ada kriteria lain sehingga ini merugikan bagi nasabah.

\section{KESIMPULAN}

Berdasarkan hasil dari penelitian yang dilakukan oleh peneliti terkait Kajian Fatwa DSN MUI Klausal Denda dan Ganti Rugi Pada Skim KPR Syariah, dapat disimpulkan bahwa penerapan Klausal Sanksi dan Ganti Rugi masih terjadi dua pendapat ada yang megatakan bahwa sudah sesuai dengan syariat Islam dan ada yang mengatakan tidak sesuai dengan syariat Islam, pendapat pertama mengatakan, jika tidak diterapkan maka perusahaan rugi dan memberi jera pada nasabah yang mampu namun tidak membayar kewajiban yang pada waktu akad telah disepakati di awal untuk membayar kewajibab. Serta dana ini nantinya akan diperuntukkan sebagai dana sosial. Pendapat kedua, tidak boleh menerapkan sanksi dengan mengambil harta, Kreditur (bank) yang menerima dana denda, mendapatkan keuntungan dan ini termasuk riba. 


\section{DAFTAR PUSTAKA}

AAOIFI. (2010). Accounting, Auditing, and Governance Standard for International Financial Institution. Buku.

Aidil Novia. (2016). kontribusi fiqih legal maxim dalam fatwa-fatwa ekonomo syariah Dewan Syariah Nasional Majelis Ulama Indonesia (DSNMUI). Jurnal, 12(1), 79-104.

Baidhowi. (2017). Rekonstruksi Akad Murabahah. Jurnal, 8(2), 221-239.

Dewan Syariah Nasional MUI. (2014). Himpunan Fatwa Keuangan Syariah. Buku, jakarta(erlangga).

Erwandi Tarmizi. (2019). Harta Haram Muamalah Kontenporer. Buku, 17.

Fadli. (2017). Penerapan denda murabahah menurut fatwa dewan syariah nasional dsn/mui (studi di pt. Bank muamalat indonesia cabang padangsidimpuan). Jurnal, 12(2), 199-231.

Farid Budiman. (2013). Karakteristik Akad fPembiayaan Al-Qardh Sebagai Akad Tabarru. Jurnal, 28(3), 406-408.

Fauzan, ahmad kamil dan M. (2007). kitab undang-undang hukum perbankan dan ekonomi syariah. Buku, cet 1 .

Mahkamah Agung RI. (2013). Kompilasi Hukum Ekonomi Syariah.

Maimun. (2013). Reorientasi Ijtihad Kontemporer : analisis Hukum Islam. Jurnal, 11(2), 155-163.

Sutedi, A. (2009). perbankan syariah tinjauan dan beberapa segi hukum. Buku, bogor(ghalia indonesia).

Wahbah Al-Zuhaili. (2008). al-muamalat al-malyat al-Mu'ashira. Buku.

zawawi. (2016). Fatwa klausul sanksi dalam akad: studi komparatif fatwa Dewan Syariah Nasional (DSN) Majelis Ulama Indonesia (MUI) dan Majma' Fiqh Organisasi Konferensi Islam (OKI). Jurnal, 16(2), 237-255.

Zity, A. A. A. (2008). Noal-Mu'amalat al-Maliyyat al-Mu'asirat wa Atharu Nazariyatu al-dharai' fi Tatbiqatuha. Buku. 